\title{
TOWARD ANIMAL LIBERATION? \\ The New Anti-Cruelty Provisions in Canada AND ThEIR IMPACT ON THE STATUS OF ANIMAlS
}

\author{
LYNE LÉTOURNEAU
}

There has been a progressive change in western philosophical thought regarding animals. While animals were once regarded as objects, valuable solely in relation to their use to humans, there is now a substantial movement to recognize animals as inherently valuable and deserving of the same moral status as humans. This change in attitude is not reflected in amendments to the Criminal Code anti-cruelty provisions. The new provisions recognize that animals have the capacity to feel pain. However, the provisions do not protect animals independently of the benefits that animals provide to humans. Still categorized as property. animals do not share the moral status of humans. Further, under the new provisions, animals do not have legal rights. Therefore. despite changes in the law regarding animals, no animal liberation is taking place.
La philosophie occidentale à lëgard des animaux a évolué de manière progressive. Alors que l'on considerait jadis les animaux comme des objets, ayant une valeur uniquement dans la mesure ou ils étaient utiles aux humains, il existe de nos jours un important mouvement qui vise à reconnaitre leur valeur inhérente et à leur accorder le méme droit moral que les humains. Toutefois les amendements aux dispositions anti-cruauté du Code criminel ne reflètent pas ce changement d'attitude. Les nouvelles dispositions reconnaissent que les animaux peuvent souffrir. Cependant ces dispositions ne protègent pas les animaux autrement que pour les bénéfices qu'ils procurent aux humains. Ils sont toujours considérés comme une propriété et ne jouissent pas du mème droit moral que les humains. De plus, en veriu de ces nouvelles dispositions, les animaux n'ont pas de droits légaux. C'est pour cette raison qu'il n'y a pas de véritable mouvement de libération des animaux et ce, malgré les changements à la loi.

\section{TABLE OF CONTENTS}

I. THE Evolution IN MORAL THINKING ............. 1041

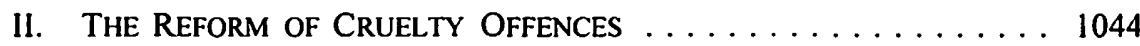

III. THE CONCEPT OF "MORAL Status" . . . . . . . . . . . . . 1046

IV. THE RECOGNITION OF ANIMAL INTERESTS . . . . . . . . . . . 1047

V. THE PRECEDENCE of Human INTERESTS $\ldots \ldots \ldots \ldots \ldots \ldots 1051$

VI. Conclusion: THE RoAd to ANimal Liberation . . . . . . . . 1054

\section{The Evolution in MORAL Thinking}

From the evolution of "animal as object" to that of "animal as person," the history of western philosophical thinking bears witness to a progressive acknowledgement of animals (or, at least, of some animals) as full members of the moral community, along with all human beings.'

Among thinkers from Aristotle (384-322 B.C.E.) to René Descartes (1596-1650 C.E.), including the religious thinkers of the middle ages and most humanists of the

Rescarch Professor, Department of Animal Sciences, Laval University. She is a member of the Research Center on Reproductive Biology, Laval University.

See S.F. Sapontzis. "The Evolution of Animals in Moral Philosophy" (1984) 3 Between the Species 61. 
Renaissance period, there existed a well-established belief in the west that humans are superior to animals, and that belief excluded animals from moral consideration. ${ }^{2}$ Reduced to objects, animals were considered means to human ends or purposes. ${ }^{3}$ Certain theorists who were part of this tradition, such as Saint Thomas Aquinas (12251274) and Emmanuel Kant (1724-1804), nonetheless insisted that humans ought to treat animals humanely because cruelty towards animals leads to cruelty towards humans. ${ }^{4}$ As a result, humans had no direct moral duties to animals, only duties involving or regarding them, which are in fact indirect duties to humans.

Paralleling the concept of "animal as object" was the notion of humane treatment of animals. Closely related to the position of Aquinas and Kant, this notion was based on the idea that animals must benefit from human kindness and compassion. Developed by Greek thinkers such as Pythagoras (sixth-century B.C.E.), Empedocles (490-435 B.C.E.) and Plutarch (50-125 C.E.), this principle permeated popular culture throughout the middle ages and found a voice in the Renaissance period through Michel de Montaigne (1533-1592). ${ }^{6}$

In 1789, Jeremy Bentham applied utilitarian doctrine to animals and called for their legal protection against all acts of cruelty. ${ }^{7}$ Echoing Bentham's view, utilitarian philosopher John Stuart Mill (1806-1873) advocated the legal protection of animals in

: This view is related to anthropocentrism, which holds that the interests of humans are morally more important than the interests of animals or nature in its totality: F. De Roose \& P. Van Parijs, La pensée écologiste - Essai d'inventaire à l'usage de ceux qui la pratiquent comme de ceux qui la craignent (Brussels: De Boeck-Wesmael, 1991) at 23. For a brief overview of the origins of anthropocentrism, see A. Bondolfi, L'homme et l'animal - Dimensions éthiques de leur relation (Fribourg: Éditions Universitaires, 1995) at 10-28; G. Chapouthier, Au bon vouloir de l'homme. l'animal (Paris: Denoël, 1990) at 91-95; L. Létourneau \& T. Leroux, "Vers un nouveau droit? Les développements biomédicaux et l'èthique animale" in R. Côté \& G. Rocher, eds., Entre droit et rechnique: enjeux normatifs et sociaux (Montreal: Thémis, 1994) 295 at 301-303; T. Regan \& P. Singer, eds., Animal Rights and Human Obligations, 2d ed. (Englewood Cliffs: Prentice Hall, 1989) at Iff; and P. Singer, Animal Liberation, rev. ed. (New York: Avon Books, 1990) at 185-202 [hereinafter Animal Liberation].

For an in-depth analysis, see B. Cyrulnik, ed., Si les lions pouvaient parler - Essais sur la condition animale (Paris: Gallimard, 1998); E. de Fontenay, Le silence des bêtes - La philosophie à l'ëpreuve de l'animalité (Paris: Fayard, 1998); T. Gontier, De l'homme à l'animal: Montaigne el Descartes ou les paradoxes de la philosophie moderne sur la nature des animaux (Paris: Vrin, 1998); and R. Sorabji, Animal Minds and Human Morals: The Origins of the Western Debate (Ithaca: Cornell University Press, 1995).

Such ends or purposes include entertainment, sport, the production of food, skin, fur or other products, transportation, biomedical research, education, etc.

T. Aquinas, "On Killing Living Things and the Duty to Love Irrational Creatures," cited in Regan \& Singer, supra note 2 at 11-12; and E. Kant, "Duties in Regard to Animals," cited in ibid. at 23. T. Regan, "Animal Rights and Welfare" in The Encyclopedia of Philosophy Supplement (New York: Macmillan Reference USA, 1996) 27 [hereinafter "Animal Rights and Welfare"].

Sce L. Létourneau, L'expérimentation animale: l'homme, l'éthique et la loi (Montreal: Thémis. 1994) at 15-22; and Létourneau \& Leroux, supra note 2 at 303-306.

See J. Bentham, An Introduction to the Principles of Morals and Legislation (Oxford: Clarendon Press, 1879) at 311, n. 1; and J. Bentham, The Theory of Legislation, ed. by C.K. Ogden (London: Routledge \& Kegan Paul, 1950) at 428-29. 
1848. ${ }^{8}$ There were no further significant developments in relation to utilitarian thinking on animals until 1975, when Peter Singer revisited Bentham's thesis and popularized it with the general public and the members of the modern animal protection movement. In Animal Liberation, ${ }^{9}$ Singer argued that, in assessing the consequences of our actions, it is necessary to take into account the interests of every being affected and to give these interests the same weight as the similar interests of any other being. This principle of equal consideration of interests constitutes the basis of the moral equality between humans and animals within the utilitarian doctrine.

In addition to utilitarianism, another view of the moral status of animals was proposed during the course of the nineteenth century. In 1899, Henry S. Salt advanced the principle of animals' rights. Salt claimed for "animals, as for men, in so far as it is compatible with the public welfare, a measure of individuality and freedom, a space in which to live their own lives - in a word, Rights." ${ }^{10}$ Indeed, he argued, "if, as is usually conceded, there are rights of men, then we assert there are also, in due degree, rights of animals." It was eighty-four years later, however, that Salt's ideas became influential. Following in Salt's footsteps, in 1983 Tom Regan presented a comprehensive argument in favour of animal rights. In The Case for Animal Rights, ${ }^{12}$ Regan defended a position which rests on a structure of basic moral rights (to respectful treatment and not to be harmed), which are shared equally by all individuals who possess an inherent value, be they moral agents or moral patients, humans or nonhumans. These basic moral rights cannot be violated or sacrificed for the benefit of others. They erect protective fences around animals and impose limits on what humans can do to them. Central to Regan's view is the idea that animals are never to be treated as means to human ends, however good those ends may be. ${ }^{13}$ He thus elevates animals to the status of "person."

There is no doubt that in addition to Peter Singer and Tom Regan, other scholars have made important contributions to the discussion on the status of animals. ${ }^{14}$

R.D. Ryder, Victims of Science: The Use of Animals in Research, 3d ed. (London: National AntiVivisection Society, 1983) at 131.

Supra note 2.

10 H.S. Salt, "The Rights of Animals" (1899) 10 Int'l J. of Ethics 206 at 210 . Salt was probably the first to publish an essay on animal rights in a philosophical journal: R. Magel. Keyguide to Information Sources in Animal Rights (London: Mansell Publishing, 1989) at 9.

"Salt, ibid.

1: T. Regan. The Case for Animal Rights (Berkeley: University of California Press, 1983) at 344 [hereinafter The Case for Animal Rights].

"Animal Rights and Welfare," supra note 5 at 28.

See especially C.J. Adams, Neither Man nor Beast: Feminism and the Defense of Animals (New York: Continuum, 1994); S.R.L. Clark, Animals and Their Moral Sianding (London: Routledge, 1997); D. DeGrazia, Taking Animals Seriously: Mental Life and Moral Status (Cambridge: Cambridge University Press, 1996) [hereinafter Taking Animals Seriously]; D.A. Dombrowski. Babies and Beasts - The Argument from Marginal Cases (Urbana: University of Illinois Press. 1997); J. Donovan \& C.J. Adams, eds., Beyond Animal Rights - A Feminist Caring Ethic for the Treatment of Animals (New York: Continuum, 1996); M.G. Forrester. Persons, Animals and Fetuses - An Essay in Practical Ethics (Dordrecht: Kluwer, 1996); A. Linzey, Animal Rights A Christian Assessment of Man 's Treatment of Animals (London: SCM Press, 1976); M. Midgley, Animals and Why They Matter (Harmondsworth: Penguin Books, 1983); E.B. Pluhar, Beyond 
However, the views articulated by Singer and Regan have emerged as dominant and have played major roles in setting the ideologies which now inspire the animal protection movement. ${ }^{15}$ Both of these positions radically change the instrumental status afforded to animals in traditional moral thinking, that is the concept of animal as object and the principle of humane treatment of animals, by granting them moral status - by recognizing them as full members of the moral community, along with all human beings. This position, of course, is not shared by all contemporary moral philosophers. ${ }^{16}$ Notwithstanding, there now appears to be a fairly broad consensus that animals are members of the moral community. As moral philosopher L.W. Sumner affirms, "no one has succeeded in making a persuasive case in favour of any criterion of moral standing that will exclude all animals from the moral domain." 17

Based on this evolution in moral thinking, one might assume that the law relating to the protection of animals in western societies ${ }^{18}$ has evolved to reflect a similar acknowledgement that animals are worthy of moral consideration in their own right; that is, that they count or matter morally.

\section{The REFORM OF CRUelty OfFEnCES}

In Canada, an effort is presently underway to reform the Criminal Code anti-cruelty provisions. ${ }^{19}$ The amendments, which are proposed in Bill C-10, An Act to amend the

Prejudice: The Moral Significance of Human and Nonhuman Animals (Durham: Duke University Press, 1995); J. Rachels, Created from Animals - The Moral Implications of Darwinism (Oxford: Oxford University Press, 1991); R. Rodd, Biology, Ethics, and Animals (Oxford: Clarendon Press, 1990); B.E. Rollin, Animal Rights and Human Morality, rev. ed. (Buffalo: Prometheus, 1992); S.F. Sapontzis, Morals, Reason, and Animals (Philadelphia: Temple University Press, 1987); and M.A. Warren, Moral Status: Obligations to Persons and Other Living Things (Oxford: Clarendon Press, 1997).

G.L. Francione, Rain Without Thunder: The Ideology of the Animal Rights Movement (Philadelphia: Temple University Press, 1996) at 12 [hereinafter Rain Without Thunder].

See especially P. Carruthers, The Animal Issue: Moral Theory in Practice (Cambridge: Cambridge University Press, 1992); J. Chanteur, Du droit des bètes à disposer d'elles-mémes (Paris: Éditions du Seuil, 1993); L. Ferry, Le notvel ordre écologique - L'arbre, l'animal et l'homme (Paris: Bernard Grasset, 1992); R.G. Frey, Interests and Rights: The Case Against Animals (Oxford: Clarendon Press, 1980); and M.P.T. Leahy, Against Liberation - Putting Animals in Perspective, rev. ed. (London: Routledge, 1994).

L.W. Sumner, "Animal Welfare and Animal Rights" (1988) 13 J. of Medicine \& Philosophy 159. The law related to the protection of animals includes both anti-cruelty legislation, which creates general offences of cruelty toward animals, as well as welfare legislation, which prescribes in the context of specific animal uses how animals ought to be treated, housed and cared for.

Criminal Code, R.S.C. 1985, c. C-46, ss. 444-47. As stated in a Consultation Paper prepared by the Department of Justice,

These sections describe offences that involve killing. maiming, wounding, injuring or endangering cattle (444); or other animals that are kept for a lawful purpose (445); or more generally causing unnecessary pain, suffering or injury to an animal by any means (446); or causing unnecessary suffering by various specific acts, such as baiting an animal, transporting an animal in an unsafe manner, releasing a bird from captivity for the purpose of being shot, and neglecting to provide adequate food, water, shelter or care (446). Section 447 concerns the keeping of a cockpit. 
Criminal Code (cruelty to animals and firearms) and the Firearms $A c t,{ }^{20}$ aim to consolidate the current provisions and to add new elements." The highlights of the Bill include the following:

providing a definition for "animal," as "a vertebrate, other than a human being, and any other animal that has the capacity to feel pain";

- moving current provisions relating to cruelty to animals from the property Part of the Criminal Code (Part XI - Wilful and Forbidden Acts in Respect of Certain Property) to a newly created Part V.1, entitled Cruelty to Animals; making it an offence to intentionally kill an animal brutally or viciously, regardless of whether the animal dies immediately, or, in other words, whether or not the animal suffers pain;

- adding a new offence dealing with harming a law enforcement animal; and

- increasing penalties relating to cruelty to animals offences and offering a broader range of criminal sanctions.

According to legal scholar Elaine L. Hughes and veterinarian Christiane Meyer, the reform proposals reflect no fundamental change in philosophy from the current law: ${ }^{22}$

Although the government proposes to prohibit cruelty to animals under the reformed law because they have the capacity to suffer, and not because of their status as property, the notion of protecting animals because they have inherent value and rights to lead their natural lives is not even open for discussion. ${ }^{23}$

Not all agree. Some suggest that the new provisions will "elevate the status of animals"24 and that "key animal rights concepts have been included." 25 To illustrate, the Legislative Summary of Bill C-10 includes the following:

Certain groups - including farmers and hunters - were troubled about some of the new aspects of the cruelty to animals provisions. For example, they were concerned about removing the cruelty

Canada, Crimes Against Animals: A Consultation Paper (Ottawa: Communication and Executive Services Branch, 1998) at 5 [hereinafter Paper].

37th Parl., 2d Sess., 2002. Bill C-10 is a reprint of Bill C-15B (37th Parl., 1st Sess.), as adopted by the House of Commons at Third Reading on 4 June 2002. It "reintroduces measures originally contained in Bill C-15B's predecessor, Bill C-17 ... which was introduced in the previous Parliament but which died on the Order Paper at dissolution": Library of Parliament. Bill C-IO: An Act to amend the Criminal Code (cruelty 10 animals and firearms) and the Firearms Act (Legislative Summary LS-433E) (Ottawa: Library of Parliament, 2002) at I [hereinafter Library of Parliament].

$21 \quad$ Library of Parliament, ibid. at 3.

$22 \quad$ E.L. Hughes \& C. Meyer, "Animal Welfare Law in Canada and Europe" (2000) 6 Animal L. 23 at 41. The authors' comment is directed at Bill C-17. However, since the changes proposed in Bill C-17 were very similar to those included in Bill C-10, the authors' comment remains relevant. Ibid.

Canadian Federation of Humane Societies, Update on Cruelty to Animals Section of the Criminal Code (4 December 2002), online: Canadian Federation of Humane Societies <www.cfhs.ca $>$ (date accessed: 9 December 2002).

Standing Committee on Justice and Human Rights (16 October 2001) (Alan Herscovici). 
provisions from the property sections of the Criminal Code and creating a new Part for these provisions. David Broth, general manager of the B.C. Cattlemen's Association, had stated the following: "It's moving from property rights to almost human rights" and added that "we do have some concern about what this is indicating." 26

During parliamentary debate on Bill C-15B, Vic Toews, Member of Parliament for the Canadian Alliance, referred to the following statement made by Liz White, director of the Animal Alliance of Canada, in reference to the proposed legislation: "I can't overstate the importance of this change. This elevation of animals in our moral and legal view is precedent setting and will have far, far reaching effects."27

Do the proposed changes to the Criminal Code anti-cruelty provisions enhance in any way the status of animals? More particularly, in regard to animal liberation, do these changes acknowledge that animals have moral status? ${ }^{28}$

\section{ThE CONCEPT OF "MORAL STATUS"}

In order to answer these questions, one could draw on the characteristic elements of Singer's and Regan's viewpoints and compare the theoretical "ideal" that they pose with the new anti-cruelty provisions. One could ask whether these provisions reflect either an animal rights position or utilitarian thinking. Such an analysis, however, is complex and would require a detailed examination of both the state and scope of animal protection law in Canada, as well as of the socio-historical context of its development, both of which go beyond the aim of the present article. A more limited, although not less valuable, approach based on the definition of "moral status" will be used here.

According to moral philosopher David DeGrazia, "A has moral status if and only if A's interests have some moral weight, independently of their effects on other beings who have moral status." ${ }^{29}$ DeGrazia defines an interest as "something that figures favourably in the welfare, good or prudential value profile ... of a particular individual." ${ }^{30}$ Examples of interests arguably shared by humans and animals include experiential well-being such as the avoidance of suffering, freedom, and life. ${ }^{31}$ Normal adult humans are paradigmatic cases of individuals who have moral status. ${ }^{32}$ As DeGrazia explains,

Whether protected by rights or deontological duties, taken into account in utilitarian maximization, or subject to some other form of serious consideration, the interests of normal adult humans have moral

Library of Parliament, supra note 20 at 25.

House of Commons Debates (10 April 2002) at 1605 (Vic Toews). See also at 1600.

This article is not on the legal effects, or absence thereof, of the proposed changes to the Criminal Code anti-cruelty provisions. It focuses on the moral attitude toward animals conveyed by the new provisions.

D. DeGrazia, "Equal Consideration and Unequal Moral Status" (1993) 31 Southern J. of Philosophy 17 at 25 [hereinafter "Equal Consideration"].

lbid. at $17-18$.

Ibid. at 18.

Ibid. at 25 . 
weight. And the weight of their interests is not just due to the way in which protecting them redounds to the benefit of other beings - as Kant suggested that animal interests mattered only insofar as respecting or disregarding them affected human beings (so that we had only 'indirect duties' to animals). ${ }^{33}$

It follows that the new anti-cruelty provisions will acknowledge that animals have moral status if two conditions are met: (1) the proposed changes recognize that animals possess interests; and (2) these interests matter, and are therefore protected irrespective of any benefit to human beings.

\section{The RECOGNITION OF ANIMAL INTERESTS}

Under the law, animals are the subject of ownership. They are property. ${ }^{34}$ This has been their legal status throughout the course of legal history, ${ }^{35}$ and this will remain their legal status after the enactment of the new anti-cruelty provisions. As stated by J. Robert Gardiner, lawyer and co-chair of the Status of Animals Committee of the Canadian Federation of Humane Societies:

[Moving cruelty to Part V.I from the property Part XI] does not in any way denigrate from the fact that animals are often a person's property. Improving the Criminal Code is not going to allow anyone to take away my dog. The cow you purchased, bred or received as a gift is as much your property as your kitchen table. ${ }^{36}$

In his book Animals, Property, and the Law, legal scholar Gary L. Francione clearly sets out what it means to be "property":

To classify something as property in a legal sense is to say that the thing is to be regarded solely as a means to the end determined by human property owners... If we say that an animal is property, we mean that the animal is to be treated under the law primarily (if not exclusively) as a means to human ends, and not as an end in herself. ${ }^{37}$

To characterize animals as property therefore embodies the moral judgment that animals and their human owners are not of equal worth. ${ }^{38}$ In contrast to the concept of animals

In common law, see, e.g., B. Ziff, Principles of Property Law, 3d ed. (Toronto: Carswell, 2000) at 122. In civil law, see e.g. P.-C. Lafond, Précis de droit des biens (Montreal: Thémis, 1999) at 132; and S. Normand, Introduction au droit des biens (Montreal: Wilson \& Lafleur, 2000) at 60. 64-66.

3 See S.M. Wise, "The Legal Thinghood of Nonhuman Animals" (1996) 23 B.C. Envtl. Aff. L. Rev. 471.

36. Canadian Federation of Humane Societies, Brief to the Standing Committee on Justice and Human Rights re: Bill C-15 - Section 15 Cruelty 10 Animals (Nepean: Canadian Federation of Humane Societies) at 6, online: CFHS <www.chs.ca/CriminalCode/CI5analysis.pdfs (date accessed: 9 December 2002).

G.L. Francione, Animals, Property, and the Law (Philadelphia: Temple University Press, 1995) at 46 [hereinafter Animals, Property, and the Law]. See also at 42-46.

3. See J. Tannenbaum, "Animals and the Law: Property, Cruelty, Rights" (1995) 62 Social Research 539 at $594-95$. 
as property, all human beings are "persons" under the law, ${ }^{39}$ and as persons, human beings are holders of rights. ${ }^{40}$ Some of these rights are rights in the basic and strict sense of the term. They are moral rights, rights "which every man is entitled to enjoy." ${ }^{\text {"4l }}$ As moral rights, they provide persons with strong prima facie protection that cannot be compromised without the most compelling reasons. ${ }^{42}$ In this respect, moral rights recognize the inherent value of persons or human beings. As Francione underscores in reference to moral rights,

Generally speaking. when we say that someone has a right, we mean that the person has some value that requires our respect whether or not our exploitation of that person would be beneficial to others. The point of having a right is to have something that stands as a sort of barrier between the holder of the right and everyone else. ${ }^{43}$

Thus, whereas humans are persons under the law, animals are property. More specifically, animals are the property of persons. This dichotomy between "property" and "person" is very important because in both common law and civil law traditions, ${ }^{44}$ it establishes a hierarchy between beings in accordance with their species. Indeed, as legal scholar Roberto Andorno explains, the dichotomy between "property" and "person" conveys a relationship of inequality and subordination between the two categories. ${ }^{45}$ Accordingly, from a moral viewpoint, the legal status of animals as property clearly indicates that animals are considered inferior to humans.

This dichotomy does not mean that the law does not recognize that animals have interests. Legal restrictions may be placed on the use of property. ${ }^{46}$ Indeed, as defined by Blackstone, the right of private ownership "consists in the free use, enjoyment, and disposal of all [one's] acquisitions, without any control or diminution, save only by the laws of the land." ${ }^{17}$ In the case of animals, restrictions consist of various statutes and regulations now forming the body of animal protection law in Canada, and include the offences of cruelty to animals found in the Criminal Code. These legal constraints on the use of animals recognize that animals possess interests.

Mike Radford affirms that "Historically, trials concerning animals generally arose from disagreement over ownership, or the rights and liabilities which might ensue from ownership." ${ }^{48}$ As he explains,

W. Blackstone, Commentaries on the Laws of England, vol. 1 (New York: Garland Publishing, 1978) at 123. See also R. Andorno, La distinction juridique entre les personnes et les choses À l'épreuve des procréations artificielles (Paris: L.G.D.J., 1996) at 6-7.

Blackstone, ibid. at 122.

Ibid. at 123.

Rain Without Thunder, supra note 15 at 49.

Animals, Property, and the Law, supra note 37 at 8.

The distinction between "property" and "person" is an axiom of the legal system: Andorno, supra note 39 at 3-5.

lbid. at 6.

Animals, Property and the Law, supra note 37 at 43-44, 9.

Blackstone, supra note 39 at 138 [emphasis added].

M. Radford, Animal Welfare Law in Britain: Regulation and Responsibility (Oxford: Oxford University Press, 2001) at 99. 
the common law was concerned with animals only in so far as they constituted property, and the very minimal protection against abuse which it provided originated entirely in the importance the courts attached to safeguarding the inviolability of a person's possessions; there was no regard tor an animal's inherent needs. Accordingly, the owner of an animal might bring proceedings against a third party who had injured or abused it, on the basis that such conduct had reduced the animal's value, but the owner himself could treat it however he pleased, and authorize his employees likewise, in exactly the same way that he could choose to do whatever he wished with his inanimate property. ${ }^{49}$

Thus, the effect of legislative intervention "has been to qualify the common law freedom which allowed humans, especially owners and those acting under their authority, to treat other species in whatever way they saw fit." ${ }^{0}$ This represented a major change in law and, more importantly, introduced a basis on which to protect animals irrespective of any owners' possessory or proprietary interests. Animals should be protected by law from abusive treatment because, unlike inanimate property, they have the capacity to feel pain.

Indeed, the enactment of the first anti-cruelty statute in Great Britain ${ }^{51}$ followed a profound shift in British sentiments toward the natural world:

it was between 1500 and 1800 that there occurred a whole cluster of changes in the way in which men and women, at all social levels, perceived and classified the natural world around them. In the process some long-established dogmas about man's place in nature were discarded. New sensibilities arose towards animals, plants and landscape. The relationship of man to other species was redefined; and his right to exploit those species for his own advantage was sharply challenged. ${ }^{52}$

Ibid. at 101. There exists no common law offence of cruelty to animals: A.G. Stevenson, "Animals and the Scope of Anti-Cruelty Legislation" (1997) 1 Juridical Rev. 12 at 15. Radford, supra note 48 at 102.

31 Commonly known as Martin's Act in honour of its sponsor Richard Martin, Member of Parliament for Galway, An Act to Prevent the Cruel and Improper Treatment of Cattle (3 George IV, c. 71), was the first statute of its kind in Great Britain. Directed towards the protection of animals, it made it an offence to wantonly and cruelly beat, abuse, or ill-treat any horse, mare, gelding, mule, ass, ox, cow, heifer, steer, sheep, or other cattle. Martin's $A c t$ was the first national statute to protect animals from human cruelty. However, as early as 1641 , the legal code of the Massachusetts Bay Colony in the United States provided that "No man shall exercise any Tirranny or Crueltie towards any brute Creature which are usuallie kept for man's use": E.S. Leavitt \& D. Halverson, "The Evolution of Anti-Cruelty Laws in the United States" in Animal Welfare Institute, ed., Animals and their Legal Rights: A Survey of American Laws from 1641 to 1990, 4th ed. (Washington: Animal Welfare Institute, 1990) 1.

K. Thomas, Man and the Natural World: A History of the Modern Sensibility (New York: Pantheon Books, 1983) at 15. Keith Thomas argues that a number of prevalent intellectual and social factors at that time brought about this shift in sentiments. They are the development of natural history, the expanding knowledge of our world, the theory of evolution, the experience people had with animals in their everyday lives which led to a sentimental view of animals as pets and objects of contemplation, a new longing for the countryside, the progress of cultivation, and the births of the conservation movement and vegetarianism. 
Parallel changes of social attitude toward animals occurred in other countries. ${ }^{53}$ As described by legal scholars David Favre and Vivien Tsang,

The nineteenth century saw a significant transformation of society's attitude toward animals, which was reflected in the legal system. The legal system began the century viewing animals as items of personal property not much different than a shovel or plow. During the first half of the century, lawmakers began to recognize that an animal's potential for pain and suffering was real and deserving of protection against its unnecessary infliction. The last half of the nineteenth century saw the adoption of anti-cruelty laws which became the solid foundation upon which today's laws still stand. ${ }^{54}$

Echoing more sympathetic sentiments toward the suffering of animals, anti-cruelty laws have promoted a better treatment of animals by acknowledging their capacity to feel pain. This holds true for the current Criminal Code provisions relating to cruelty to animals. ${ }^{55}$ As for the reform proposals, this point is evident in the creation of Part V.1 on cruelty to animals. As noted in a legislative summary on Bill C-10,

This modification is more than merely cosmetic because it would change the way the Criminal Code regards animals in that the cruelty to animals offences would no longer be treated, in large part, as property crimes and animals would be regarded essentially as beings that feel pain. ${ }^{56}$

Therefore, although they may not have the effect of altering the legal status of animals as property, the proposed changes to the Criminal Code anti-cruelty provisions impose legal constraints on the use of animals and implicitly recognize that animals, unlike inanimate property, possess an interest in having a favourable experiential welfare or more specifically, in avoiding pain, suffering and injury. In addition, because Bill C-10 condemns both the vicious killing of animals and the killing without a lawful purpose, it can be argued that the proposed changes also implicitly admit that animals have an interest in life, or in remaining alive. ${ }^{57}$

In conclusion, the proposed amendments to the Criminal Code anti-cruelty provisions recognize that animals possess interests. However, the question remains whether the interests are protected irrespective of any benefit to human beings. The answer to this question will depend on the rationale advanced in order to justify the reform proposals. Unless this second condition is met, it is impossible to conclude that the new cruelty offences acknowledge that animals have moral status.

See generally C.D. Niven, History of the Humane Movement (New York: Transatlantic Arts, 1967) at $97 \mathrm{ff}$; and P. Jamieson, "Duty and the Beast: The Movement in Reform of Animal Welfare Law" (1990) 16 U. Queensland L.J. 238. D. Favre \& V. Tsang, "The Development of Anti-Cruelty Laws During the 1800's" (1993) 1 Detroit College L. Rev. 1 at 1-2.

ss See Paper, supra note 19 at 7,11 .

st. Library of Parliament, supra note 20 at 3.

37 Of course, it is one thing to accept that animals possess interests, but quite another to admit that these interests are relevantly similar to that of human beings. See "Equal Consideration," supra note 29 at 19-24; Taking Animals Seriously, supra note 14 at 231-48; and P. Singer. Practical Ethics, 2d ed. (Cambridge: Cambridge University Press, 1993) at 83-134. 


\section{The Precedence of Human Interests}

What is the basis of the protection afforded to animals by the new anti-cruelty provisions? Regan suggests two possible bases:

The first is human centered: We are to protect various animals because it is in our interest to do so. Thus, for example, ... we may make cruelty to animals illegal because it offends humans (or some of them).... The second possible basis is animal centered: We are to protect various animals, not if or as this coincides with human interest; we are to protect them because they themselves have a legitimate interest in being protected. ${ }^{58}$

The human-centered basis supposes that "animal life and interests ought to be protected only if or as these are in harmony with human life and interests." ${ }^{59}$ The animalcentered basis "is the one that recognizes the independent value of animal life."

Is the rationale of Bill $\mathrm{C}-10$ human-centered or animal-centered? To the extent that human interests are relied on at any point to justify the new anti-cruelty provisions, this shall indicate that the provisions do not protect animal interests independently of their effects on human beings.

In a consultation paper describing key reform issues, the government affirms that one argument in support of reform is to protect human society from violence directed toward its members:

[A modernized animal abuse law] could function as a more effective deterrent to morally reprehensible behaviour, behaviour which threatens not only the welfare of animals, but also the moral and physical welfare of society at large. Intentional cruelty has long been considered by law enforcement experts as an indicator of the potential for increasing violence and dangerousness, and studies have shown that many serial killers and mass murderers have a history of animal abuse.... Animal abuse may also be an indicator of other forms of violence in the home, such as abuse of a child, spouse or elderly person. $^{6 !}$

The same document states that the proper aim of the criminal law is "to contribute to the maintenance of a just, peaceful and safe society by prohibiting behaviour that causes or threatens to cause serious harm to individuals or society."

Speaking to the House of Commons about the provisions of Bill C-15B, Paul Harold Macklin, Parliamentary Secretary to the Minister of Justice and Attorney General of Canada, emphasized that "there is a greater social interest which is achieved by treating cruelty to animals more seriously. There is increasing scientific evidence that shows a

T. Regan, All That Dwell Therein: Essays on Animal Rights and Environmental Ethics (Berkeley: University of California Press, 1982) at 160 [hereinafter All That Divell Therein].

Ibid. at 161.

Ibid.

Paper, supra note 19 at 1.

Ibid. at 5. 
correlation between animal cruelty and subsequent violence against humans." ${ }^{63}$ This view is shared by the Canadian Federation of Humane Societies:

Animal abuse deserves attention not only because of a concern to prevent unnecessary infliction of suffering upon animals, but also because cruelty to animals is a related cause of other social and criminal problems in society. ${ }^{64}$

These statements clearly establish the harmony of interests in protecting animals from cruel treatment on one hand, and protecting human society from violence directed toward its members on the other. Consequently, although the proposed changes to the Criminal Code anti-cruelty provisions confirm that animals deserve to be protected because they are able to experience pain, suffering, injury and death, these provisions concomitantly serve important human interests. That being the case, it cannot be said that the new legislation protects animals irrespective of any benefit to human beings. Thus, the basis of Bill C-10 is human-centered, not animal-centered.

Interestingly, this explains why the new anti-cruelty provisions do not create legal rights for animals. ${ }^{65}$ It is not uncommon for people to infer that animals have legal rights because they are the beneficiaries of the various statutes and regulations protecting them. ${ }^{66}$ Basically, the argument runs, these various provisions give animals the right not to be treated in violation of the law. However, as Regan underscores, there is a distinction between "(a) being protected by a law and (b) having a legal right that is created or acknowledged by a law. For not everything protected by a law itself has

House of Commons Debates (10 April 2002) at 1545 (P.H. Macklin). See also Library of Parliament, supra note 20 at 2-3.

Canadian Federation of Humane Societies, supra note 36 at 4 . See also at 14.

Regan makes the following distinction between legal and moral rights in The Case for Animal Rights, supra note 12 at 267-68: "Whether individuals have legal rights, he declares, depends on the laws and other legal background (e.g., the constitution) of the society in which they live." According to Regan, legal rights arise as the result of the creative (legal) activity of human beings. As such, legal rights are subject to great variation in scope, not only among different countries at the same time, but also in the same country at different times. In contrast, moral rights are universal: "if any individual $(A)$ has such a right, then any other individual like $(A)$ in the relevant respects also has the right." In addition, moral rights are equal in that all who possess them possess them equally. Finally, unlike legal rights, moral rights do not originate in the creative acts of any one individual or group. They do not "come to be" in the way legal rights do. They prevail whether or not they are socially acknowledged and legally enforced. A legal right is a right that is recognized and enforced by a legal system. On the distinction between legal and moral rights, see generally J.-Y. Goffi \& L. White, Le philosophe et ses animaux - Du statut éthique de l'animal (Nîmes: Éditions Jacqueline Chambon, 1994) at 17-18, 26-27, 95.

All That Dwell Therein, supra note 58 at 156; J. Passmore, "The Treatment of Animals" (1975) $36 \mathrm{~J}$. of the History of Ideas 195 at 212. See J. Feinberg, "Human Duties and Animal Rights" in J. Feinberg, Rights, Justice, and the Bounds of Liberty - Essays in Social Philosophy (Princeton: Princeton University Press, 1980) 185 at 193-94 [hereinafter "Human Duties and Animal Rights"]; W.D. Lamont, "Duty and Interest - (II)" (1942) 17 Philosophy 3 at 13-17; Leavitt \& Halverson, supra note 51 at 3; C. Morris, "The Rights and Duties of Beasts and Trees: A Law Teacher's Essay for Landscape Architects" (1964) 17 J. of Legal Education 185 at 189; and Tannenbaum, supra note 38 at 581-85. 
a legal right.. ${ }^{167}$ It is generally agreed that not all duties entail rights. ${ }^{68}$ Only duties that are the correlative of claims share some special relation to rights. ${ }^{69}$

According to Hohfeld's classic conception of a legal claim, " $X$ has a legal claim against $Y$ with respect to some action if and only if $Y$ has a legal duty to $X$ to perform that action." one, or, in other words, as the correlative of a duty owed to one by some second party. Such a conception of a claim entails that there may not be a claim, and hence no legal right, without a direct duty as opposed to an indirect duty, or a duty regarding one."

But what does it mean for a duty to be owed to someone? This is a question left unanswered by Hohfeld. Generally speaking, two different accounts of the nature of a claim, and that of its correlative duty to one prevail among jurisprudents and philosophers. These are the interest account of claims and the control account of claims. The accounts are inferred respectively from two competing theories which aim to

All That Dwell Therein, ibid. at 156.

See J. Feinberg, Social Philosophy (Englewood Cliffs: Prentice-Hall, 1973) at 62-63.

See J. Feinberg, "The Nature and Value of Rights" in Feinberg, supra note 66 at 143; and J.S. Mill, Utilitarianism (c. 1861), reproduced in Collected Works of John Stuart Mill, vol. 10 (Toronto: University of Toronto Press, 1969) 203 at 249-51.

C. Wellman, A Theory of Rights: Persons under Laws, Institutions, and Morals (Totowa: Rowman \& Allanheld, 1985) at 8. See also W.N. Hohfeld, "Some Fundamental Legal Conceptions as Applied in Judicial Reasoning" (1913-1914) 23 Yale L.J. 16; reprinted in W.W. Cook. ed.. Fundamental Legal Conceptions as Applied in Judicial Reasoning (New Haven: Yale University Press, 1966) 23 at 38 [hereinafter "Legal Conceptions (1)"]. Hohfeld is the most celebrated of English-speaking twentieth-century legal analysts: J.W. Harris. Legal Philosophies (London: Butterworths, 1980) at 77. In his leading article "Some Fundamental Legal Conceptions as Applied in Judicial Reasoning," Hohfeld showed that the word "right" is used generically and indiscriminately to denote any sort of legal advantage, whether a claim, a liberty (Hohfeld used the term privilege), a power, or an immunity. In order to avoid conceptual confusion, Hohfeld distinguished sharply between these four concepts: "Legal Conceptions (I)," ibid. at 36ff. While recognizing this very broad and indiscriminate use of the term "right," however. Hohfeld maintained that a legal right, in its limited and proper meaning, is a legal claim: ibid. at 36-38: and W.N. Hohfeld, "Fundamental Legal Conceptions as Applied in Judicial Reasoning" (1916-1917) 26 Yale L.J. 710, reprinted in Cook, ed., ibid. at 71 . Hohfeld's pioneering work in the analysis of the concept of a right relates to legal rights. Be that as it may. the distinctions he developed apply to the moral sphere: See J. Waldron. "Introduction" in J. Waldron. ed.. Theories of Rights (Oxford: Oxford University Press, 1984) 1 at 7; and Wellman, ibid. at 131-159. Hohfeld's legal concepts also have their counterparts in the norms of various organized social institutions, such as churches, private clubs, academic institutions, and business corporations, as well as in bodies of conventional norms, like rules of informal games, codes of etiquette, and conventional morality: ibid. at 107-19. Legal rights also have four distinctive features. They are presented in C.D. Stone, "Should Trees Have Standing? - Toward Legal Rights for Natural Objects?" (1972) 45 Southern California L. Rev. 450 at $458 \mathrm{ff}$. However, I shall not discuss them. For an examination of these features, or of some aspects thereof, see generally Animals, Property, and the Law, supra note 37 at 65-90; S.I. Burr. "Toward Legal Rights for Animals" (1975) 4 Environmental Affairs 205 at 227ff; M.A. Fox. "Misconceived Humaneness" (1978) 58 Dalhousie Rev. 230 at 235-37; R.W. Galvin. "What Rights for Animals? A Modest Proposal" (1985) 2 Pace Environmental L. Rev. 245; P. Jamieson, "The Legal Status of Animals under Animal Welfare Law" (1992) 9 Environmental \& Planning L.J. 20; D.R. Schmahmann \& L.J. Polacheck, "The Case Against Rights for Animals" (1995) 22 B.C. Envtl. Aff. L. Rev. 747 at 773-79; and J.S. Tischler, "Rights for Nonhuman Animals: $\wedge$ Guardianship Model for Dogs and Cats" (1977) 14 San Diego L. Rev. 484 at 500 fr. 
provide the proper explanation of rights in general: the interest theory of rights ${ }^{72}$ and the dominion theory of rights. ${ }^{73}$ Because the control account of claims is incompatible in principle with animals having claims to a certain treatment against human beings, it is not considered here. ${ }^{74}$ Instead, the interest account of claims is considered.

Under Joseph Raz's definition of the concept of a right, ${ }^{75} \mathrm{X}$ has a claim to a certain treatment against $\mathrm{Y}$, who has a correlative duty to $\mathrm{X}$, if and only if an interest of $\mathrm{X}$ serves as a reason for imposing a duty on $Y{ }^{76}$ Raz's interest theory of rights therefore indicates that $\mathrm{X}$ has a claim whenever the protection or advancement of an interest of $\mathrm{X}$ is recognized by a normative system, either moral, legal, or otherwise, as a reason for imposing a duty on others. ${ }^{77}$ Thus, the interest account of claims is much more accommodating to the idea of animals having claims, and thus possessing legal rights. ${ }^{78}$ As Francione states, "there appears to be nothing inherent in interest theory that would preclude it, prima facie, from applying to animals." 79 The thrust of the "interest" account is indeed to protect an individual's interest or well-being by placing duties on others.

Nevertheless, the use of the language of rights is foreclosed in the context of the proposed anti-cruelty provisions. These new provisions only give rise to indirect duties. To the extent that the protection they afford to animals concomitantly benefits human society, the duties imposed by the new provisions cannot be viewed solely as protecting animal interests for their own sake. They also protect animal interests for the sake of others. That being the case, it follows that animals' interests are not viewed by the legal system as a sufficient reason in themselves for imposing duties on human beings. As a result, the new provisions do not give rise to duties that are owed directly to animals, but rather to duties that merely concern or regard them.

\section{Conclusion: The RoAd to Animal Liberation}

In this article I have asked whether the proposed changes to the Criminal Code anticruelty provisions acknowledge that animals have moral status. Offering an argument based on the concept of "moral status," I maintain that they do not. Although the proposed amendments recognize that animals possess interests, these interests are not protected irrespective of any benefit to human beings. In the course of my argument,

72

See J. Raz, "Legal Rights" (1984) 4 Oxford J. Leg. Stud. I [hereinafter "Legal Rights"]; and J. Raz, "On the Nature of Rights" (1984) 93 Mind 194 [hereinafter "On the Nature of Rights"]. See Wellman, supra note 70.

N. MacCormick, "Children's Rights: A Test-Case for Theories in Rights" in N. MacCormick, Legal Rights and Social Democracy: Essays in Legal and Political Philosophy (Oxford: Clarendon Press, 1982) 154 at 155-56; and Waldron, supra note 70 at 12.

Raz defends an interest theory of rights. He proposes the following definition of the concept of a right: "' $x$ has a right' if and only if ... an aspect of $x$ 's well-being (his interest) is a sufficient reason for holding some other person(s) to be under a duty": "On the Nature of Rights," supra note 72 at 195.

"Legal Rights," supra note 72 at 14.

Waldron, supra note 70 at 10.

Ibid. at 12.

Animals, Property, and the Law, supra note 37 at 99. 
I have also discussed two issues which, in the context of animal protection law, often give rise to misconceptions. The two issues are the significance of the property status of animals and the idea of animals having legal rights. Mainly, I have attempted to show that anti-cruelty legislation in Canada does not lead the way to animal liberation. This is also not the case in Great Britain, where an extensive and sophisticated regulatory regime is in place.$^{80}$ For animal liberation to take place, the abolition of all uses of animals for human ends or purposes will have to be achieved.

Francione argues that, contrary to widespread belief among the contemporary animal protection movement and scholars as well, animal rights theory prescribes a practical strategy to achieve abolition incrementally and, accordingly, to move toward the recognition of the basic moral right of animals to be treated with respect. ${ }^{81}$ Indeed, as the use of animals is deeply ingrained in western society, and as our economies are heavily dependent upon such use, no animal rights advocate urges total abolition as a realistic goal. Rather, Francione suggests supporting legal reforms which will in effect eliminate "pieces" of the many forms of animal use. However, in a world where the extent of humans' use of animals has reached an unprecedented level and where, with the development of new technology, still further animal uses are contemplated (such as the breeding of genetically engineered animals to provide organs for human transplants or the production of human proteins with therapeutic potential from the milk or semen of transgenic animals), the road to animal liberation remains an uncertain one. Orthodoxy (Ph.D. Thesis, University of Aberdeen, 2000) [unpublished]. For a broad overview of the law in Britain as it relates to the protection of animals, see Radford, supra note 48 . 